J. Dairy Sci. 95:6949-6956

http://dx.doi.org/10.3168/jds.2012-5831

(C) American Dairy Science Association ${ }^{\circledR}, 2012$.

\title{
Short communication: Characterization of Shiga toxin 2-carrying bacteriophages induced from Shiga-toxigenic Escherichia coli isolated from Italian dairy products
}

\author{
G. Volponi, ${ }^{,}$D. J. Rooks,† D. L. Smith,† C. Picozzi, ${ }^{,}$H. E. Allison,† I. Vigentini, ${ }^{\star}$ R. Foschino, ${ }^{*}$ \\ and A. J. McCarthyt ${ }^{1}$ \\ *Dipartmento di Scienze e Tecnologie Alimentari e Microbiologiche, Università degli Studi di Milano, via Celoria 220133 Milano, Italy \\ †Microbiology Research Group, Institute of Integrative Biology, Biosciences Building, University of Liverpool, Crown Street, \\ Liverpool, L69 7ZB, United Kingdom
}

\begin{abstract}
Forty samples of raw milk cheese and 25 samples of raw milk itself were subjected to enrichment culture for Shiga-toxigenic Escherichia coli (STEC), and a single Shiga toxin 2- $\left(\mathrm{Stx}_{2}\right)$ positive strain was obtained from one of the cheese samples. Thus, aged cheeses in which the curd is subsequently heat treated $\left(48^{\circ} \mathrm{C}\right)$ cannot be presumed to be STEC free. Infective $\mathrm{Stx}_{2}$ bacteriophages were induced from 3 STEC strains isolated elsewhere from raw milk and 1 STEC strain from aged cheese sourced in Italy. Data on E. coli host range, morphology, genome size, and genetic variation determined by restriction fragment length polymorphism and multi-locus genotyping are presented. Although all 4 bacteriophages were found to be short-tailed Podoviridae, they exhibited considerable variation in both genome size and content. This extended to the $S t x_{2}$ genes themselves, whose sequences contained several point mutations, but these did not translate to amino acid substitutions.
\end{abstract}

Key words: Shiga-toxigenic Escherichia coli, milk and cheese, Shiga toxin bacteriophage, protected designation of origin dairy product

\section{Short Communication}

The production of Shiga toxins ( $\mathbf{S t x}$ ) is regarded as the main virulence factor of Shiga-toxigenic Escherichia coli (STEC) strains, which are responsible for severe human gastrointestinal diseases, typified by hemorrhagic colitis (HC) and hemolytic-uremic syndrome (HUS) as frequent complications (Cohen and Giannella, 1992). Most pathotypes, among them Escherichia coli O157, carry additional virulence markers such as intimin and

Received June 12, 2012.

Accepted August 9, 2012.

${ }^{1}$ Corresponding author: aj55m@liv.ac.uk enterohemolysin, encoded by eae and hly genes, respectively (LeBlanc, 2003). Shiga toxin genes are located in the genomes of bacteriophages, which are the natural vector for the spread of Shiga-toxigenic potential among E. coli and other Enterobacteriaceae through the phenomenon of lysogenic conversion (Herold et al., 2004; Gyles, 2007; Smith et al., 2007a; Strauch et al., 2008). Two Shiga toxin types exist: $\mathrm{Stx}_{1}$ and $\mathrm{Stx}_{2}$, which may or may not be present together in STEC strains (Nataro and Kaper, 1998) and although Stx $_{1}$ is highly conserved, several variants of $\mathrm{Stx}_{2}$ exist for which evidence of enhanced pathogenicity exists (Friedrich et al., 2002). The ability of lysogens to give rise to infectious virions and to transduce indigenous $E$. coli strains within the host gastrointestinal tract of mice (Acheson, 1998; Gamage et al., 2003) and sheep (Cornick et al., 2006) has been demonstrated. Therefore, Stx phages are not only responsible for the origin of STEC, but also play a key role in the pathogenesis of HC and HUS with respect to the virulence and diffusion of pathology. In fact, the dissemination of these viral genes by transduction is considered the most likely mechanism for the dynamic emergence of new STEC serotypes (Schmidt et al., 1999; Schmidt, 2001; Bielaszewska et al., 2007).

Shiga toxin phages described thus far comprise double-stranded DNA with isomeric heads and long tails (Siphoviridae) or short tails (Podoviridae); they are members of the lambdoid family because they all exhibit the organization of genetic modules first described in bacteriophage lambda, even though their genomes have a mosaic structure (Allison, 2007). Unusually for lambdoid phages, the ability of Stx phages to form multiple lysogens has been demonstrated (Fogg et al., 2007; Serra-Moreno et al., 2008) and, thus, the rapid evolution of STEC strains could have been driven by intracellular recombination events between multiple integrated prophages. Moreover, multiple copies of the Stx gene in a single E. coli genome may lead to enhancement of toxin production in vivo (Fogg et al., 2012). 
Reports on the prevalence of STEC in different environments reveal that most of the strains recovered produce only 1 type of toxin; 2 to $54 \%$ of isolates possessed the $S t x_{1}$ gene, 16 to $62 \%$ the $S t x_{2}$ gene, and up to $38 \%$ carried both $S t x_{1}$ and $S t x_{2}$ genes (Muniesa et al., 2004; Dumke et al., 2006; Beutin et al., 2007; Slanec et al., 2009). Shiga toxin 2 and its variants are more important in foodborne infection outbreaks (Bertin et al., 2001; García-Aljaro et al., 2009) and evidence exists that $\mathrm{Stx}_{2}$ is more often associated with the progression to serious disease (Boerlin et al., 1999). Cattle, sheep, and goats are the principal reservoirs of STEC (Pradel et al., 2000; Fratamico et al., 2004; Hussein and Bollinger, 2005; Kaufmann et al., 2006; Gyles, 2007; La Ragione et al., 2009) and although unpasteurized dairy products would, therefore, be expected to represent an infectious source, only isolated reports exist (VernozyRozand et al., 2005, Zweifel et al., 2010). In Italy, the sale of unpackaged raw milk for direct human consumption is authorized because it represents a means to support small farms and maintain economic activities in marginal territories; currently, 1,455 retail distributors of raw milk are on tap, located in 91 districts. Furthermore, across Europe, extensive production exists of protected designation of origin cheeses prepared from raw milk, and at least an implication of semi-hard and hard cheeses as a source of STEC in Switzerland (Stephan et al., 2008; Zweifel et al., 2010). In Italy, a national surveillance system based on voluntary notification was established in 1988 to monitor the incidence of $\mathrm{HC}$ and HUS in pediatric patients and to identify the
STEC strains associated with these syndromes (Tozzi et al., 2003). A recent episode of STEC foodborne infection involved 9 children in the Lombardy region, and in recognition of the risk associated with raw milk consumption, a ministerial ordinance requiring milk to be heated before consumption was issued (Ministero del Lavoro, della Salute e delle Politiche Sociali, 2009). To further establish and characterize the potential of raw milk and raw milk cheese to serve as a source of STEC, we describe, for the first time, Stx phages induced from $E$. coli isolated from Italian dairy products.

The bacterial strains used in this work are listed in Table 1. Strains were routinely cultured in lysogeny broth (LB; Bertani, 2004; BD Difco, Franklin Lakes, NJ), with or without $1.5 \%$ (wt/vol) agar (Merck KGaA, Darmstadt, Germany). Phage buffer (PB; LB broth supplemented with $10 \mathrm{mM} \mathrm{CaCl}$; Sambrook and Russell, 2001) was used for phage propagation. Escherichia coli CNCTC 6896, a recA441 mutant of laboratory strain K12, was the indicator strain used for routine propagation of the bacteriophages.

In this study, 40 samples of raw milk cheese (fresh and aged) and 25 samples of raw milk (from goat and cow), collected from different Alpine regions in Northern Italy, were analyzed for STEC presence. Ten grams of each sample was added to $90 \mathrm{~mL}$ of LB, supplemented with $20 \mathrm{mg} / \mathrm{L}$ of novobiocin (Sigma, St. Louis, MO; Doyle and Schoeni, 1987) homogenized in a Stomacher 400C (Seward, Worthing, UK) for 3 min and incubated at $37^{\circ} \mathrm{C}$ for $24 \mathrm{~h}$. Two microliters of this preenrichment culture were then subjected to multiplex PCR using

Table 1. Bacterial strains and bacteriophages

\begin{tabular}{|c|c|c|c|}
\hline Strain/phage & Relevant characteristics & Source & Reference \\
\hline $181181 / 2$ & E. coli $\mathrm{O} 157: \mathrm{H} 7$, Stx $x_{2}$, eae, hlyA & Cow raw milk & IZSLER $^{2}$ \\
\hline $208164 / 2$ & E. coli $\mathrm{O} 157: \mathrm{H} 7$, Stx $x_{2}$, eae, hlyA & Cow raw milk & IZSLER $^{2}$ \\
\hline SO14 & E. coli $\mathrm{NT}^{1}{ }^{1}$ Stx $x_{2}$, hlyA & Cow raw milk & CEPIS $^{3}$ \\
\hline CNCTC 6896 & E. coli Lambda-:K12 indicator strain & & $\mathrm{CNCTC}^{4}$ \\
\hline CNCTC 6246 & E. coli indicator strain & & $\mathrm{CNCTC}^{4}$ \\
\hline MC1061 & E. coli $\mathrm{K} 12$ derivative, indicator strain & & James et al. (2001) \\
\hline NCTC 12079 & E. coli $\mathrm{O} 157: \mathrm{H} 7$, Stx, Stx 2 , eae & & $\mathrm{NCTC}^{5}$ \\
\hline WG5 & E. coli $\mathrm{C}$ derivative, indicator strain & & Muniesa and Jofre (2004) \\
\hline థGV8 & Stx phage induced from 1D3.07 & & This work \\
\hline ФGV2412 & Stx phage induced from $181181 / 2$ & & This work \\
\hline$\Phi B R 2$ & Stx phage induced from $208164 / 2$ & & This work \\
\hline
\end{tabular}

${ }^{1}$ Untypeable.

${ }^{2}$ Istituto Zooprofilattico Sperimentale per la Lombardia e l'Emilia Romagna (Brescia, Italy).

${ }^{3}$ Centro Enteropatogeni Italia Settentrionale (Milan, Italy).

${ }^{4}$ Czech National Collection of Type Cultures (Prague, Czech Republic).

${ }^{5}$ National Collection of Type Cultures (Salisbury, UK). 
specific primers for amplification of $S t x_{1}, S t x_{2}$, eaeA, and hlyA genes (Fagan et al., 1999). Amplifications were performed using $1 \mathrm{U}$ of Taq DNA polymerase (5 Prime GmbH, Hamburg, Germany) in a $25-\mu \mathrm{L}$ reaction comprising $200 \mu M$ deoxyribonucleotide triphosphate (dNTP) mix (Fermentas, Vilnius, Lithuania), $3 \mathrm{mmol}$ of $\mathrm{MgCl}_{2} / \mathrm{L}$, and $200 \mathrm{nmol} / \mathrm{L}$ of each primer. Cycle conditions, carried out in a T-Gradient Biometra Thermocycler (Biometra, Göttingen, Germany) consisted of an initial denaturation at $95^{\circ} \mathrm{C}$ for $5 \mathrm{~min}, 35$ cycles of denaturation at $95^{\circ} \mathrm{C}$ for $20 \mathrm{~s}$, annealing at $60^{\circ} \mathrm{C}$ for $40 \mathrm{~s}$ and extension at $72^{\circ} \mathrm{C}$ for $90 \mathrm{~s}$, followed by a final extension at $72^{\circ} \mathrm{C}$ for $5 \mathrm{~min}$. Polymerase chain reaction products were separated on a $1.5 \%$ agarose gel stained with $0.3 \mu \mathrm{g} / \mathrm{mL}$ of ethidium bromide in Tris-acetateEDTA (TAE) buffer (40 mmol of Tris-acetate/L and $1 \mathrm{mmol}$ of EDTA/L, pH 8.0). Deoxyribonucleic acid fragments were visualized and photographed under UV illumination. A 100-bp DNA Ladder Plus (Fermentas) was included in each gel as molecular size marker.

For the isolation of presumptive STEC strains, Stxpositive samples were tested by colony hybridization with a DNA probe. For colony dot-blot hybridization, aliquots of the enrichment culture samples were plated onto Chromocult TBX agar (BD Difco). After incubation at $42^{\circ} \mathrm{C}$ for $24 \mathrm{~h}$, the appropriate dilution with the highest number of separated colonies was selected. Colonies were transferred to a nylon membrane (Hybond$\mathrm{N+}$; Amersham Pharmacia Biotech Inc., Piscataway, $\mathrm{NJ}$ ) according to a standard procedure (Sambrook and Russell, 2001) and hybridized at $65^{\circ} \mathrm{C}$ with a digoxigenin-labeled Stx probe. The Stx probes were prepared by labeling PCR amplicons from E. coli O157:H7 NCTC 12079 using a DIG High Prime kit (Roche Diagnostics GmbH, Mannheim, Germany) according to Kaufmann et al. (2006). Stringent hybridization was achieved with the DIG-DNA Labeling and Detection Kit (Roche Diagnostic Ltd., Lewes, UK) according to the manufacturer's instructions.

Shiga-toxigenic Escherichia coli strains were cultured in PB (optical density at $600 \mathrm{~nm}$ of 0.45 to 0.55 ) and treated with norfloxacin $(1 \mu \mathrm{g} / \mathrm{mL}$; Matsushiro et al., $1999)$ at $37^{\circ} \mathrm{C}$ for $1 \mathrm{~h}$ to induce phages. The cultures were diluted 10-fold in $\mathrm{PB}$ and allowed to recover at $37^{\circ} \mathrm{C}$ for $2 \mathrm{~h}$. One hundred microliters of appropriate dilutions was mixed with $100 \mu \mathrm{L}$ of $\mathrm{PB}$ and $500 \mu \mathrm{L}$ of an exponential-phase culture of E. coli strain CNCTC 6896 and examined through plaque assay using a doublelayer agar method (Muniesa and Jofre, 2004). To detect the presence of the Stx genes in phages, the plaques were transferred to a nylon membrane (Hybond-N+; Amersham Pharmacia Biotech Inc.) according to a standard procedure (Sambrook and Russell, 2001) and hybridized with digoxigenin-labeled Stx probe as described above for colony dot-blot hybridization.

After filtration through a $0.45-\mu \mathrm{m}$ membrane, phage suspensions were subjected to purification in a $\mathrm{CsCl}$ gradient according to a protocol modified from Sambrook and Russell (2001). Phage stock solutions were plated at low dilutions to produce semiconfluent lysis. After overnight incubation $(16 \mathrm{~h})$ at $37^{\circ} \mathrm{C}$, the plates were overlaid with $3 \mathrm{~mL}$ of SM buffer $(100 \mathrm{mmol}$ of $\mathrm{NaCl} / \mathrm{L}$, $8 \mathrm{mmol}$ of $\mathrm{MgSO}_{4} / \mathrm{L}$, and $50 \mathrm{mmol}$ of Tris- $\mathrm{HCl} / \mathrm{L}, \mathrm{pH}$ $7.5)$ and stored overnight $(16 \mathrm{~h})$ at $4^{\circ} \mathrm{C}$. The SM buffer was removed and the top agar was scraped into a sterile glass centrifuge tube, stirred with $10 \%$ (vol/ vol) SM buffer, centrifuged at $10,000 \times g$ for $10 \mathrm{~min}$ at room temperature, and the supernatant recovered. Chloroform $(30 \mu \mathrm{L})$ was added to each $10-\mathrm{mL}$ aliquot of phage suspension to kill any remaining cells. Deoxyribonuclease $(5 \mu \mathrm{g} / \mathrm{mL})$ and RNase $(1 \mu \mathrm{g} / \mathrm{mL}$; Sigma) were added to remove any bacterial nucleic acids, and the solution incubated for $1 \mathrm{~h}$ at $37^{\circ} \mathrm{C}$. Bacteriophages were pelleted by ultracentrifugation at $100,000 \times g$ for 30 min at room temperature, resuspended in SM buffer, and subsequently purified by $\mathrm{CsCl}$ density preformed gradient $(\mathrm{d}=1.3-1.7 \mathrm{~g} / \mathrm{mL})$ ultracentrifugation at $100,000 \times g$ for $1 \mathrm{~h}$ at room temperature. The visible band was collected and dialyzed with a $30-\mathrm{kDa}$ cut-off membrane at $4^{\circ} \mathrm{C}$ overnight $(16 \mathrm{~h})$ in dialysis buffer $(10$ mmol of Tris-HCl/L, $\mathrm{pH} 7.4 ; 10 \mathrm{mmol}$ of $\mathrm{MgSO}_{4} / \mathrm{L}$; and $0.5 \mathrm{~mol}$ of $\mathrm{NaCl} / \mathrm{L}$ ) to remove $\mathrm{CsCl}$.

To evaluate the ability of these Stx phages to infect other hosts in addition to E. coli CNCTC 6896, E. coli CNCTC 6246, DH5a, DM1187, MC1061, and WG5 strains were tested. A drop of phage suspension from the Stx phage stocks was spotted onto a monolayer plate containing each indicator strain and, after incubation at $37^{\circ} \mathrm{C}$ overnight $(16 \mathrm{~h})$, plates with a clear zone of lysis were scored as positive. The morphology of viral particles was observed by transmission electron microscopy (Philips 201, $80 \mathrm{kV}$; Philips International BV, Eindhoven, the Netherlands), after laying the suspensions on 300-mesh copper specimen grids coated with carbon film and negatively stained with $2 \%$ (wt/ vol) uranyl acetate ( $\mathrm{pH} 4.5)$.

Phage DNA, extracted with a standard protocol (Sambrook and Russell 2001) from purified stocks, was subjected to RFLP analysis by digestion with the EcoRI restriction enzyme (Fermentas). Deoxyribonucleic acid fragments were separated by agarose $(1 \% \mathrm{wt} / \mathrm{vol})$ gel electrophoresis in TAE buffer at $5 \mathrm{~V} / \mathrm{cm}$ and visualized by UV light after staining with ethidium bromide. Deoxyribonucleic acid standard fragments of MassRuler DNA Ladder Mix ready-to-use (Fermentas) were used to calculate the size of the fragments. Genome length 
was estimated by the sum of molecular weights of fragments generated by digestion. Purified bacteriophage DNA was also characterized using the multi-loci typing scheme based on lambdoid phage genome organization, using the methods described by Smith et al. (2007b).

The $S t x_{2}$ gene of each phage was sequenced using the oligonucleotides S2Aup/S2Alp for Stx $x_{2}$ subunit A and GK3/GK4 for subunit B, as described by Muniesa et al. (2004) and using oligonucleotides VT1/VT2, as described by Kaufmann et al. (2006). Sequencing was provided by Primm Srl (Milan, Italy). Nucleotide sequence analysis, assembly of the sequences, protein translation, and BLAST analyses were performed with the GenDoc Multiple Sequence Alignment Editor (http://petang. cgu.edu.tw/Bioinfomatics/Softwares/SOFTWARES/ Soft-index.htm), BioEdit Sequence Alignment Editor (http://www.mbio.ncsu.edu/BioEdit/bioedit.html), and the ClustalW Multiple Sequence Alignment Program (http://www.ebi.ac.uk/clustalw/). Nucleotide sequences obtained in this work have been deposited in the GenBank database under accession numbers from JN193428 to JN193431.

Only 1 of the 40 cheese samples tested gave a positive result after the multiplex PCR assay on the preenrichment broth culture, showing a band for the $S_{t x_{2}}$ gene only at $779 \mathrm{bp}$. That same sample yielded a single STEC strain (named 1D3.07), isolated and confirmed as Stx positive by colony-dot-blot hybridization. Amplification products for the eae and hylA genes were not detected and the STEC strain could not be serotyped. The positive sample was an Italian protected designation of origin cheese produced from raw cow milk. None of the 25 samples of raw cow milk tested positive for the presence of the Stx gene by PCR amplification of extracted DNA. These results can be added to the limited data set that already exists for STEC occurrence in dairy products: Pradel et al. (2000) found that 60 out of $603(10 \%)$ cheese samples examined were positive for Stx genes; Vernozy-Rozand et al. (2005) observed a STEC incidence of $13 \%$ in 1039 French raw milk cheeses; Rantsiou and Cocolin (2009) used quantitative PCR to report $18 \%$ Stx-positive samples in Piedmont tradi- tional cheeses manufactured from raw milk; Stephan et al. (2008) and recently Zweifel et al. (2010) reported STEC prevalences of $4.9 \%$ in 796 samples and $5.7 \%$ in 1,502 samples, respectively, of soft, semi-hard, and hard cheeses made from Swiss cows, goats, and sheep raw milk collected at the producer level. The recovery here of an STEC strain (1D3.07), lysogenic for an inducible Stx phage $(\phi G V 8)$, from a sample of Fontina cheese that had undergone heating of the curd at $48^{\circ} \mathrm{C}$ and was ripened for no less than $3 \mathrm{mo}$ at $12^{\circ} \mathrm{C}$, supports a previous study (Zweifel et al., 2010) in which it was suggested that aged raw milk cheeses are a potential source of STEC.

Other STEC isolated from raw milk samples, obtained in previous studies or kindly supplied by Italian institutions, were also investigated (Table 1). Escherichia coli O157:H7 strains 181181/2, 208164/2, and EC34 yielded amplification products of the expected size in multiplex PCR for the Stx 2 , eae, and hlyA genes; SO14, an untypable E. coli O strain, was positive for $S t x_{2}$ and hlyA genes, whereas our ID3.07 isolate, the other untypable strain, was positive for the $S t x_{2}$ gene only. Induction of prophages by norfloxacin treatment was carried out on these 5 STEC strains, and infective bacteriophages were detected in 4 of the 5 strains (not SO14) by plaque assay. A single $\mathrm{Stx}_{2}$ phage was then purified from each one of the 4 viral lysates; the purified phages (Table 1) were again shown to be Stx positive by plaque hybridization assay. Detection by plaque assay is dependent on the susceptibility of host indicator strains, as evidenced here by the variation in host range found among only 4 purified Stx phages (Table 2). More meaningful data on the prevalence of Stx phages requires the application of direct viral DNA recovery protocols in combination with quantitative PCR-based quantification (Rooks et al., 2010).

All 4 phages had a similar morphology as determined by transmission electron microscopy (Figure 1 ). The viral particles were identified as members of the Podoviridae family, characterized by a short tail and icosahedral head; base plate-like structures were not observed. The heads had a diameter of 45 to 55

Table 2. Characterization of purified Shiga toxin (Stx) phages

\begin{tabular}{|c|c|c|c|c|c|c|c|c|c|c|}
\hline \multirow[b]{2}{*}{$\begin{array}{l}\text { Isolated } \\
\text { phage }\end{array}$} & \multirow{2}{*}{$\begin{array}{l}\text { Capsid } \\
\text { diameter } \\
\quad(\mathrm{nm})\end{array}$} & \multirow{2}{*}{$\begin{array}{l}\text { Tail } \\
\text { length } \\
\text { (nm) }\end{array}$} & \multirow{2}{*}{$\begin{array}{l}\text { Genome } \\
\text { size } \\
(\mathrm{kbp})\end{array}$} & \multicolumn{6}{|c|}{ Host range $^{1}$} & \multirow{2}{*}{$\begin{array}{l}\% \text { Identity to closest match } \\
\text { sequences of } S t x_{2} \text { subunit A } \\
\text { and B genes (accession number }\end{array}$} \\
\hline & & & & $\begin{array}{c}\text { CNCTC } \\
6246\end{array}$ & $\begin{array}{c}\text { CNCTC } \\
6896\end{array}$ & DH5 $\alpha$ & DM1187 & MC1061 & WG5 & \\
\hline$\Phi \mathrm{GV} 8$ & 52 & 8 & 61 & - & +++ & - & +++ & ++ & +++ & 99.4, Ф933W (AF125520) \\
\hline$\Phi G V 2412$ & 45 & 9 & 65 & - & +++ & - & +++ & - & ++ & 99.6, O157-379 (AY633468) \\
\hline$\Phi B R 2$ & 55 & 9 & 53 & - & ++ & - & ++ & - & + & 100, VTB60 (AY633471) \\
\hline ФL34 & 52 & 10 & 58 & - & +++ & - & +++ & +++ & ++ & 99.8, VTB324 (AY633460) \\
\hline
\end{tabular}

${ }^{1}+++=$ strong lysis $;++=$ clear lysis $;+=$ weak lysis; $-=$ no lysis in the spot area. 


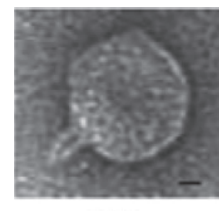

\$134

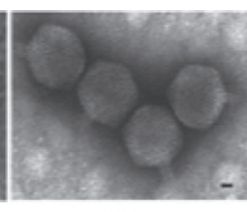

$\phi G V 8$

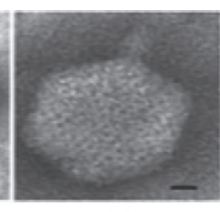

фBR2

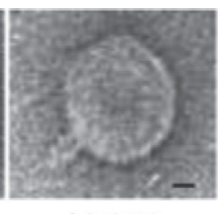

фGV2412
Figure 1. Transmission electron micrographs of the 4 purified Shiga toxin (Stx) phage isolates ( $\Phi \mathrm{L} 34, \Phi \mathrm{GV} 8, \Phi B R 2$, and $\Phi \mathrm{GV} 2412)$. Bar markers $=10 \mathrm{~nm}$.

$\mathrm{nm}$ with short tails up to $10 \mathrm{~nm}$ in length (Table 2). Mean values were obtained by measuring the dimensions of 10 individual viral particles for each of the 4 phage preparations on at least 2 different microscopic preparations. RFLP analysis of phage DNA extracts generated a unique banding pattern for each (Figure 2) and the genome sizes estimated on the basis of the total sum of the restriction fragments were also distinct and in the range of approximately 53 to $61 \mathrm{kbp}$ (Table 2). The ability of Stx phages to infect different host strains was evaluated by spotting the phage preparations on a lawn of each E. coli strain and scoring any lysis observed (Table 2). All phages were able to infect and lyse the phage propagation host E. coli CNCTC 6896; E. coli DM1187, which is a recA441 mutant that produces RecA protease constitutively and, therefore, cannot be lysogenized; and E. coli WG5, which possesses an attenuated host restriction modification system, supporting increased phage sensitivity. In contrast, E. coli CNCT 6246 and DH5 $\alpha$ were not infected by any of the 4 phages, whereas E. coli MC1061 was sensitive to $\phi$ GV8 and $\phi$ L34 phages only. The $\phi$ GV2412 and $\phi B R 2$ phages, induced from 2 strains of E. coli O157:H7, had a similar host range to one another (Table 2).

The nucleotide sequences of the toxin genes confirmed that all of the 4 phages carried the Stx 2 gene. This is in agreement with the suggested predominance of short-tailed Podoviridae carrying the Stx $x_{2}$ form of the Stx gene among inducible Stx phages (Smith et al., 2007b; McDonald et al., 2010). The Stx $x_{2}$ subunit A and $\mathrm{B}$ gene sequences exhibited close homology to various previously described phage-borne Stx genes (Table 2; Supplementary Figure 1, available online at http:// www.journalofdairyscience.org/): the $S t x_{2}$ sequence of $\phi B R 2$ was absolutely identical to that of the VTB60 phage induced from an $\mathrm{O} 136: \mathrm{H}^{-}$E. coli strain (Muniesa et al., 2004); the $\phi$ L34 Stx 2 subunit A and B genes were sufficiently similar to the Shiga-like toxin from phage VTB324 induced from an O177:H25 E. coli strain (Muniesa et al., 2004) to enable its identification as an $S t x_{2 c}$ variant (Meyer et al., 1992).

The genotypic variation detected in the 4 purified Stx phages is illustrated in Figure 3. As predicted by the data of Smith et al. (2007b), confirming the inherent genetic mosaicism of Stx phages, each purified bacteriophage had a unique profile based on the distribution of variants of specific loci. This was confirmed by the construction of a Jaccard single linkage dendrogram (Figure 3). The sequenced Stx phages $\phi 24 b, 933 \mathrm{~W}$, and P27, and bacteriophage lambda were also included in the analysis. All of the short-tailed phages (Podoviridae) share the tail fiber gene type VTTF (Figure 3 ; otherwise, the genetic heterogeneity indicated by the RFLP analysis (Figure 2) is reflected by the PCR based multi-loci typing.

In spite of abundant literature related to the characterization of Stx phages isolated from the environment, fecal material, sewage, and water (Gamage et al., 2004; Muniesa et al., 2004; Muniesa and Jofre, 2004; GarcíaAljaro et al., 2009), no data exist on phages induced from STEC isolated from milk or cheese. Here, 4 Stx

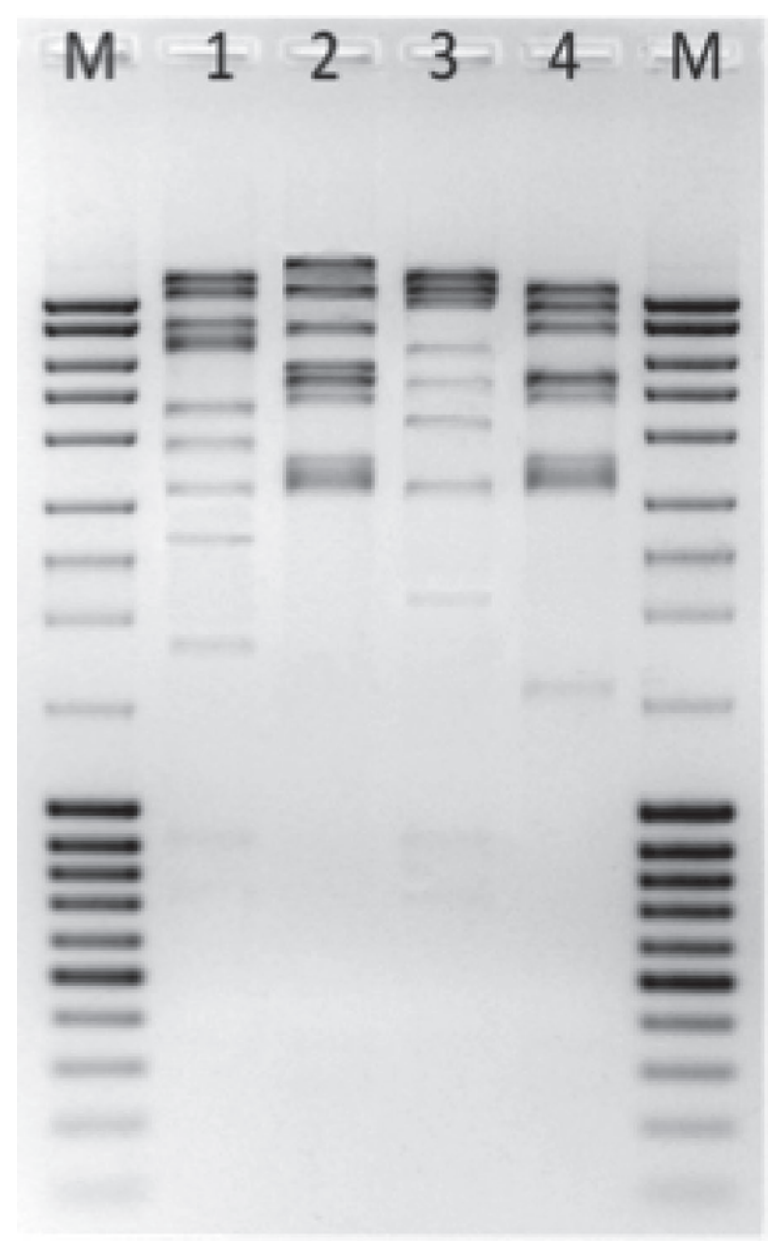

Figure 2. Restriction fragment length polymorphism (RFLP) banding patterns of EcoRI restriction enzyme- (Fermentas, Vilnius, Lithuania) digested Shiga toxin (Stx) phage DNA. M = molecular markers; $1=\Phi \mathrm{GV} 8 ; 2=\Phi \mathrm{GV} 2412 ; 3=\Phi \mathrm{L} 34 ; 4=\Phi \mathrm{BR} 2$. 


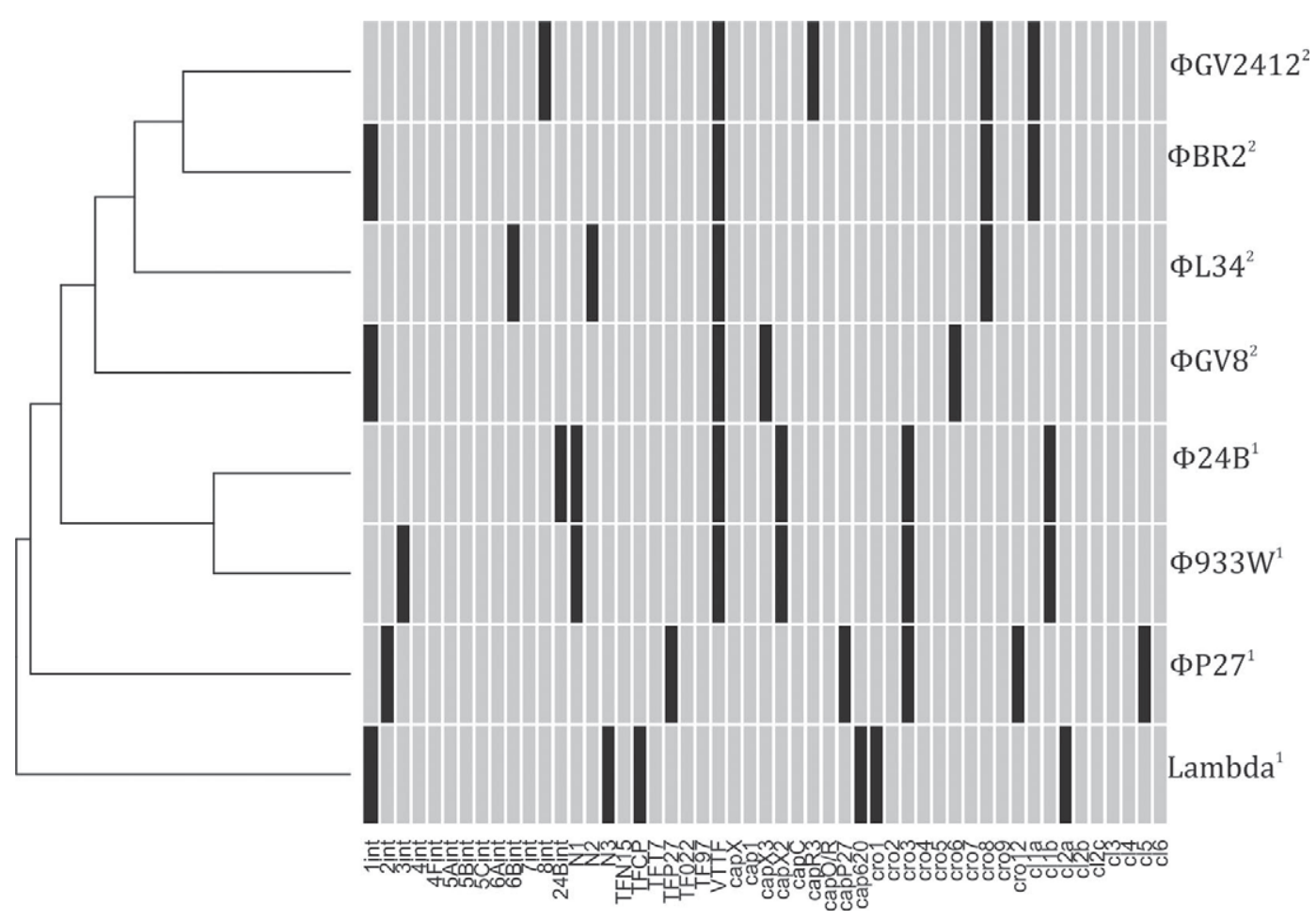

Figure 3. Diagrammatic representation of the presence and absence of genetic loci in lambdoid phages. For full gene variant names and sources, see Smith et al. (2007b). ${ }^{1}$ Sequenced phage genomes: Lambda (J02459); \$P27 (AJ298298); Ф24B (HM208303); Ф933W (AF125520). ${ }^{2}$ Purified Shiga toxin (Stx) phage isolates (Table 1). The figure indicates the presence (black) and absence (gray) distribution of PCR products for each gene variant, and a Jaccard dissimilarity dendrogram of the data.

phages were induced from STEC strains isolated from different sources and dairy products, yet all had similar morphologies and carried the $S t x_{2}$ gene. Both the RFLP and multi-locus characterization data sets (Figures 2 and 3) confirm that Stx phages are genetically heterogeneous (Muniesa et al., 2004; Allison, 2007). This genetic variation also extended partly to the $S t x_{2}$ gene itself, even in this small subset of induced Stx phages, further emphasizing the dynamic state of lambdoid phage evolution and its potential contribution to the emergence of new foodborne STEC strains.

\section{ACKNOWLEDGMENTS}

The authors are grateful to Paolo Boni (Istituto Zooprofilattico Sperimentale della Lombardia e dell'Emilia Romagna (IZSLER), Brescia, Italy) and Mirella Pontello (Dipartimento di Sanità pubblica - Microbiologia - Virologia, Università degli Studi di Milano, Milan, Italy) for providing some strains. Many thanks to Franco Faoro (Dipartimento di Scienze Agrarie e Ambientali, Università degli Studi di Milano, Milan, Italy) for his help and advice in the preparation of micrographs. This work was supported by Ministero
Italiano dell'Università e della Ricerca (Rome, Italy), PRIN 2007 national project (prot 2007PWS2PL), and the Department for Environment, Food and Rural Affairs (Defra, London, UK).

\section{REFERENCES}

Acheson, D. W. 1998. Nomenclature of enterotoxins. Lancet 351:1003. Allison, H. E. 2007. Stx-phages: Drivers and mediators of the evolution of STEC and STEC-like pathogens. Future Microbiol. 2:165-174.

Bertani, G. 2004. Lysogeny at mid-twentieth century: P1, P2, and other experimental systems. J. Bacteriol. 186:595-600.

Bertin, Y., K. Boukhors, N. Pradel, V. Livrelli, and C. Martin. 2001. Stx2 subtyping of Shiga toxin-producing Escherichia coli isolated from cattle in France: Detection of a new Stx2 subtype and correlation with additional virulence factors. J. Clin. Microbiol. 39:3060-3065.

Beutin, L., A. Miko, G. Krause, K. Pries, S. Haby, K. Steege, and N. Albrecht. 2007. Identification of human-pathogenic strains of Shiga toxin-producing Escherichia coli from food by a combination of serotyping and molecular typing of Shiga toxin genes. Appl. Environ. Microbiol. 73:4769-4775.

Bielaszewska, M., R. Prager, R. Köck, A. Mellmann, W. Zhang, H. Tschäpe, P. I. Tarr, and H. Karch. 2007. Shiga toxin gene loss and transfer in vitro and in vivo during enterohemorrhagic Escherichia coli O26 infection in humans. Appl. Environ. Microbiol. 73:3144-3150.

Boerlin, P., S. A. McEwen, F. Boerlin-Petzold, J. B. Wilson, R. P. Johnson, and C. L. Gyles. 1999. Associations between virulence 
factors of Shiga toxin-producing Escherichia coli and disease in humans. J. Clin. Microbiol. 37:497-503.

Cohen, M. B., and R. A. Giannella. 1992. Hemorrhagic colitis associated with Escherichia coli O157:H7. Adv. Intern. Med. 37:173-195.

Cornick, N. A., A. F. Helgerson, V. Mai, J. M. Ritchie, and D. W. K. Acheson. 2006. In vivo transduction of an Stx-encoding phage in ruminants. Appl. Environ. Microbiol. 72:5086-5088.

Doyle, M. P., and J. L. Schoeni. 1987. Isolation of Escherichia coli O157:H7 from retail fresh meats and poultry. Appl. Environ. Microbiol. 53:2394-2396.

Dumke, R., U. Schröter-Bobsin, E. Jacobs, and I. Röske. 2006. Detection of phages carrying the Shiga toxin 1 and 2 genes in waste water and river water samples. Lett. Appl. Microbiol. 42:48-53.

Fagan, P. K., M. A. Hornitzky, K. A. Bettelheim, and S. P. Djordjevic. 1999. Detection of Shiga-like toxin $\left(\mathrm{stx}_{1}\right.$ and $\left.\mathrm{stx}_{2}\right)$, intimin (eaeA), and enterohemorrhagic Escherichia coli (EHEC) hemolysin (EHEC hlyA) genes in animal feces by multiplex PCR. Appl. Environ. Microbiol. 65:868-872

Fogg, P. C. M., S. M. Gossage, D. L. Smith, J. R. Saunders, A. J. McCarthy, and H. E. Allison. 2007. Identification of multiple integration sites for Stx-phage $\phi 24_{\mathrm{B}}$ in the Escherichia coli genome, description of a novel integrase and evidence for a functional antirepressor. Microbiology 153:4098-4110.

Fogg, P. C. M., J. R. Saunders, A. J. McCarthy, and H. E. Allison. 2012. Cumulative effect of prophage burden on Shiga toxin production in Escherichia coli. Microbiology 158:488-497.

Fratamico, P. M., L. K. Bagi, E. J. Bush, and B. T. Solow. 2004. Prevalence and characterization of Shiga toxin-producing Escherichia coli in swine feces recovered in the National Animal Health Monitoring System's Swine 2000 study. Appl. Environ. Microbiol. 70:7173-7178.

Friedrich, A. W., M. Bielaszewska, W.-L. Zhang, M. Pulz, T. Kuczius, A. Ammon, and H. Karch. 2002. Escherichia coli harboring Shiga toxin 2 gene variants: Frequency and association with clinical symptoms. J. Infect. Dis. 185:74-84.

Gamage, S. D., A. K. Patton, J. F. Hanson, and A. A. Weiss. 2004 Diversity and host range of Shiga toxin-encoding phage. Infect. Immun. 72:7131-7139.

Gamage, S. D., J. E. Strasser, C. L. Chalk, and A. A. Weiss. 2003. Nonpathogenic Escherichia coli can contribute to the production of Shiga toxin. Infect. Immun. 71:3107-3115.

García-Aljaro, C., M. Muniesa, J. Jofre, and A. R. Blanch. 2009. Genotypic and phenotypic diversity among induced, stx2-carrying bacteriophages from environmental Escherichia coli strains. Appl. Environ. Microbiol. 75:329-336.

Gyles, C. L. 2007. Shiga toxin-producing Escherichia coli: An overview. J. Anim. Sci. 85(Suppl.):E45-E62.

Herold, S., H. Karch, and H. Schmidt. 2004. Shiga toxin-encoding bacteriophages - Genomes in motion. Int. J. Med. Microbiol. 294:115-121.

Hussein, H. S., and L. M. Bollinger. 2005. Prevalence of Shiga toxinproducing Escherichia coli in beef cattle. J. Food Prot. 68:22242241.

James, C. E., K. N. Stanley, H. E. Allison, H. J. Flint, C. S. Stewart, R. J. Sharp, J. R. Saunders, and A. J. McCarthy. 2001. Lytic and lysogenic infection of diverse Escherichia coli and Shigella strains with a verocytotoxigenic bacteriophage. Appl. Environ. Microbiol. 67:4335-4337.

Kaufmann, M., C. Zweifel, M. Blanco, J. E. Blanco, J. Blanco, L. Beutin, and R. Stephan. 2006. Escherichia coli O157 and non-O157 Shiga toxin-producing Escherichia coli in fecal samples of finished pigs at slaughter in Switzerland. J. Food Prot. 69:260-266.

La Ragione, R. M., A. Best, M. J. Woodward, and A. D. Wales. 2009. Escherichia coli O157:H7 colonization in small domestic ruminants. FEMS Microbiol. Rev. 33:394-410.

LeBlanc, J. J. 2003. Implication of virulence factors in Escherichia coli O157:H7 pathogenesis. Crit. Rev. Microbiol. 29:277-296.

Matsushiro, A., K. Sato, H. Miyamoto, T. Yamamura, and T. Honda. 1999. Induction of prophages of enterohemorrhagic Escherichia coli O157:H7 with norfloxacin. J. Bacteriol. 181:2257-2260.
McDonald, J. E., D. L. Smith, P. C. Fogg, A. J. McCarthy, and H. E. Allison. 2010. High-throughput method for rapid induction of prophages from lysogens and its application in the study of Shiga toxin-encoding Escherichia coli strains. Appl. Environ. Microbiol. 76:2360-2365

Meyer, T., H. Karch, J. Hacker, H. Bocklage, and J. Heesemann. 1992. Cloning and sequencing of a Shiga-like toxin II-related gene from Escherichia coli O157:H7 strain 7279. Zentralbl. Bakteriol. 276:176-188.

Ministro del Lavoro, della Salute e delle Politiche Sociali. 2009. Misure urgenti in materia di produzione, commercializzazione e vendita diretta di latte crudo per l'alimentazione umana. Gazzetta Ufficale della Repubblica Italiana, Rome, Italy.

Muniesa, M., J. E. Blanco, M. de Simón, R. Serra-Moreno, A. R Blanch, and J. Jofre. 2004. Diversity of stx $x_{2}$ converting bacteriophages induced from Shiga-toxin-producing Escherichia coli strains isolated from cattle. Microbiology 150:2959-2971.

Muniesa, M., and J. Jofre. 2004. Factors influencing the replication of somatic coliphages in the water environment. Antonie Van Leeuwenhoek 86:65-76.

Nataro, J. P., and J. B. Kaper. 1998. Diarrheagenic Escherichia coli. Clin. Microbiol. Rev. 11:142-201.

Picozzi, C., R. Foschino, A. Heuvelink, and R. Beumer. 2005. Phenotypic and genotypic characterization of sorbitol-negative or slowfermenting (suspected O157) Escherichia coli isolated from milk samples in Lombardy region. Lett. Appl. Microbiol. 40:491-496.

Pradel, N., V. Livrelli, C. De Champs, J.-B. Palcoux, A. Reynaud, F. Scheutz, J. Sirot, B. Joly, and C. Forestier. 2000. Prevalence and characterization of Shiga toxin-producing Escherichia coli isolated from cattle, food, and children during a one-year prospective study in France. J. Clin. Microbiol. 38:1023-1031.

Rantsiou, K., and L. Cocolin. 2009. Survey of Shiga-like toxin producing Escherichia coli in foods of animal origin of the Piedmont region in Italy. Page 75 in Book of Abstracts (Annals of Microbiology, 59, Special Issue) of ll National Congress of Societa Italiana di Microbiologia Agro-alimentare ed Ambientale (SIMTREA), Sassari, Italy

Rooks, D. J., Y. Yan, J. E. McDonald, M. J. Woodward, A. J. McCarthy, and H. E. Allison. 2010. Development and validation of a $\mathrm{qP}-$ CR-based method for quantifying Shiga toxin-encoding and other lambdoid bacteriophages. Environ. Microbiol. 12:1194-1204.

Sambrook, J., and D. W. Russell. 2001. Molecular Cloning: A Laboratory Manual. 2nd ed. Cold Spring Harbor Laboratory, Cold Spring Harbor, NY

Schmidt, H. 2001. Shiga-toxin-converting bacteriophages. Res. Microbiol. 152:687-695.

Schmidt, H., M. Bielaszewska, and H. Karch. 1999. Transduction of enteric Escherichia coli isolates with a derivative of Shiga toxin 2-encoding bacteriophage $\varphi 3538$ isolated from Escherichia coli O157:H7. Appl. Environ. Microbiol. 65:3855-3861.

Serra-Moreno, R., J. Jofre, and M. Muniesa. 2008. The CI repressors of Shiga toxin-converting prophages are involved in coinfection of Escherichia coli strains, which causes a down regulation in the production of Shiga toxin 2. J. Bacteriol. 190:4722-4735.

Slanec, T., A. Fruth, K. Creuzburg, and H. Schmidt. 2009. Molecular analysis of virulence profiles and Shiga toxin genes in food-borne Shiga toxin-producing Escherichia coli. Appl. Environ. Microbiol. 75:6187-6197.

Smith, D. L., C. E. James, M. J. Sergeant, Y. Yaxian, J. R. Saunders, A. J. McCarthy, and H. E. Allison. 2007a. Short-tailed Stx phages exploit the conserved YaeT protein to disseminate Shiga toxin genes among enterobacteria. J. Bacteriol. 189:7223-7233.

Smith, D. L., B. M. Wareing, P. C. M. Fogg, L. M. Riley, M. Spencer, M. J. Cox, J. R. Saunders, A. J. McCarthy, and H. E. Allison. 2007b. Multilocus characterization scheme for Shiga toxin-encoding bacteriophages. Appl. Environ. Microbiol. 73:8032-8040.

Stephan, R., S. Schumacher, S. Corti, G. Krause, J. Danuser, and L. Beutin. 2008. Prevalence and characteristics of Shiga toxinproducing Escherichia coli in Swiss raw milk cheeses collected at producer level. J. Dairy Sci. 91:2561-2565. 
Strauch, E., J. A. Hammerl, A. Konietzny, S. Schneiker-Bekel, W. Arnold, A. Goesmann, A. Pühler, and L. Beutin. 2008. Bacteriophage 2851 is a prototype phage for dissemination of the Shiga toxin variant gene 2c in Escherichia coli O157:H7. Infect. Immun. 76:5466-5477.

Tozzi, A. E., A. Caprioli, F. Minelli, A. Gianviti, L. De Petris, A. Edefonti, G. Montini, A. Ferretti, T. De Palo, M. Gaido, and G. Rizzoni., and the Hemolytic Uremic Syndrome Study Group. 2003. Shiga toxin-producing Escherichia coli infections associated with hemolytic uremic syndrome, Italy, 1988-2000. Emerg. Infect. Dis. 9:106-108
Vernozy-Rozand, C., M. P. Montet, M. Berardin, C. Bavai, and L. Beutin. 2005. Isolation and characterization of Shiga toxin-producing Escherichia coli strains from raw milk cheeses in France. Lett. Appl. Microbiol. 41:235-241.

Zweifel, C., N. Giezendanner, S. Corti, G. Krause, L. Beutin, J. Danuser, and R. Stephan. 2010. Characteristics of Shiga toxinproducing Escherichia coli isolated from Swiss raw milk cheese within a 3-year monitoring program. J. Food Prot. 73:88-91. 